\title{
Effect of Trade Liberalization on Economic Growth in the Panel of ASIAN Economies
}

\author{
Imran Ullah \\ PhD Scholar, Department of Economics \\ Institute of Management Sciences, Peshawar \\ imranullah961@yahoo.com \\ Muhammad Tufail \\ Lecturer, Department of Management Sciences \\ University of Buner, Bunir \\ tufyl86@gmail.com \\ Muhammad Rafiq \\ Associate Professor, Institute of Management Sciences, Peshawar \\ muhammad.rafiq@imsciences.edu.pk
}

\begin{abstract}
The present study has investigated the effects of the trade liberalization on the Economic Growth of ASIAN economies. For the sake of investigation, we took the data from 1985 to 2014 for empirical analysis, which is based on a panel of 34 countries. We have estimated the dynamic panel estimation was performed and for this purpose Generalized Method of Moment (GMM) was used. The findings of the current study have confirmed that the openness impact on the growth of economics is positive. As the openness allow utilization of comparative advantage, diffusion of knowledge, increasing scale of economies, technology transfer and exposure to competition. It is therefore, suggested that government should take prudent steps to further liberalize the trade to gain from trade.
\end{abstract}

Keywords: trade liberalization, Economic growth, ASIAN economies, GMM, trade openness

\section{Introduction}

The discovery of trade routes and improvement in transport technology increases world trade for centuries (David and Scott, 2005). Remarkable changes in the pace of globalization or openness have been observed in the last two decades (1980-2000) of the twentieth century. Trade between integrated countries is on unprecedented level (Stern, (2001) and openness in is now considered an important component of a liberal policy of economics (Obstfled and Rogoff, (1996); Winters, (2001); and Mackay and Winters, (2004)]. Trade liberalization increases incomes and reduce poverty and also affect income distribution (Winters, (2001) \& David and Scott, 2005). Since late 1970s the 
global level economic policies experienced certain fundamental changes while the role of World Trade Organization (WTO) is phenomenal in helping and quickening the process of liberal trade since 1995. Openness is the main factor which boosts economic growth and the same growth in turn helps in creating further avenues of development and prosperity (Pradhan et al., 2017\&Fukuda, K. (2019).

Countries involved in liberal trade uses different approaches to gain from trade. Strategy of import substitution and government control is an example of those approaches adopted by the East Asian countries in mid of 1960s. These strategies were found to improve the growth rate of Gross Domestic Product (GDP), leaving standard and provided sustainability during oil shocks in 1970 and in recession years 1980s. Economic theories are no short to put forward many reasons why liberal trade is the cause of economic growth (Winters, (2002); Stern, (2001); Mackay and Winters, (2004). It allows easier imports, knowledge and technological spillovers, allocative efficiency while an increased competition as well. Trading enhances the growth and the availability of a variety of goods at reasonable prices. A combined research study of IMF and World Bank shows that slow economic development in the third world countries is mostly because of the restriction on trade (Manwa et al., 2019).

In today's globalized world, trade openness is substantial to facilitate investors and to acquire inputs and new technologies for efficiency and growth. International market reachability can diversify exports through import substitution, expand domestic industries by attracting FDI and creating employment opportunities. Growth in FDI and it influence is not only of an academic interest but policy makers also love the subject (Sun et al., 2020).

Moreover, as most of today economies are deeply connected through financial markets, development and openness of financial sector can further amplify growth and development through ease and improved allocation of resources. According to the World Bank Report (1993), active participation in international trade with developed economies is proved to be crucial for the growth of many East Asian countries. Many economists argued that trade openness enable third world countries to pace up with technologically advanced countries through transfer of technology [Obstfled and Rogoff, (1996); and Sharer et al, (1998)]. Romer (1993), Grossman and Helpman (1991) and Barro and Sala I-Martin (1995) and other found trade openness to significantly impact economic growth [Dollar (1992), Edwards (1998), Harrison (1996), Barro and Lee (1994), Easterly and Levine (2001), Dollar and Kraay (2002), Irwin and Tervio (2000)].Specific objective of the study is; Indeed the vast bulk of the literature claims that trade openness could promote the economic development of a country through various channels as by attracting FDI, stimulating domestic investment and creating employment opportunities. The present work attempts to research the issue of liberal trade and economic growth in case of ASIAN economies which is mostly neglected by the literature.

\section{Significance of the study}


Most of the previous literature have examined the influence of liberal trade on various economic problems. But unfortunately these effects are often observed from single country prospective, the present study add to the existing literature is to examine the effects of trade liberalization on economic development of ASIAN economies.

\section{Review of Literature}

\section{Theoretical Review}

The way International trade shapes itself and concept of wellbeing among different nations are..... It adjoins the trade patterns to comparative advantage, and suggests the engagement in trade for nations so that each will specialize in the production of goods. This production has a competitive edge as it would happen in situations with less opportunity costs before doing trade beyond boarders. Therefore, all the nations try to export things with superior value in comparison to their competitors. In the context of the classical Ricardian international trade model, a country specializes through technological advantage, whereas the Heckscher-Ohlin model basis itself on comparative advantage in factors endowment. The conventional international trade theories emphasizes on resource reallocation to gain efficiency and increase aggregate national output.

Moreover, according to static models of monopolistic competition and economies of scales, trade openness lead to increase in availability of many differentiated products for consumers and secondly, it increases competition which results lower prices due to economies of scale (Krugman 1979, 1980). The lower prices benefit consumers as a result of increase in real wages. However, the size and distribution of such gains from trade expansion may be heterogeneous, but many economists suggest positive impact of international trade on aggregate national income. Nevertheless, opening of closed economy to international trade may promote either primary sectors or technologically intensive sectors depending upon comparative advantage in initial factor endowments. On the basis of this perspective, a country may struggle to gain from trade if it is characterized by technological backwardness and may only specialize in primary sectors (Grossman and Helpman., 1991). Beside, trade liberalization and its potential impact on growth is subject to technological assistance, role in R\&D and protectionism, and many empirical analysis suggest positive growth effects but the size of effects has been found small.

\section{Empirical Review}

Literature is available to showcase and provide substantial evidence of worthy contribution of liberal trade to the betterment of the world. Greenaway et. al. (2002) conducted a cross-country analysis of 73 developing countries on three different measures of trade liberalization and their relationship with GDP growth rate: First measure on which he based his analysis is non-tariff, his aim was to look for the economy's tendency towards socialism and to see the control of the state over major exports; secondly, quotas, tariff, hurdles in the exports and exchange rate and marketers alignment disorders; and finally, he took a dummy construct for the structural adjustment 
program which is a World Bank (WB) indicator. Empirical results were obtained by using the Ordinary Ordinary Least Square (OLS) technique was used to get empirical results. The first two measures resulted in proving the positive and significant effect of the trade liberalization on growth but in short run. On the other hand WB indicator's effect was insignificant. However, overall results indicate that liberal trade effects on GDP growth in the long run are not time consuming.

In the same manner, Kemal et. al., (2002) studied the macroeconomic factors of growth in Pakistan considering the variables that have substantial impact on the growth rate e.g. pouring money in physical capital, population growth, government spending, devaluation and liberal trade.OLS estimation was used for 1959-60 to 2000-01 period.Results indicate the insignificance of the impact of the openness on growth. However, there are several reasons such as irregular behavior macroeconomic constructs, scarce data, and many other problems faced by Pakistan. Another study tried to investigate how openness can affect poverty in Pakistan (Mohsin et. al. 2001). This study took time period of 1963-64 to 1993-94. They took head count indexing as a mean of determining poverty and exports and imports as percentage of GDP for openness and reached to a conclusion that poverty has decreased in Pakistan as trade liberalization went up. One thing is easy to deduce from the literature under review is that the effect of trade liberalization is different in on different aspects economic growth. The reason behind this peculiarity is the whimsical policies on the part of the government and other organization elements as Khan and Qayyum (2007) argued that there is a positive and strong connection among trade and financial sector with economic development.

Nourzad and Powell (2003) carried a studyon the nexus between the levels of growth and openness in forty seven third world countries during 1965-1990. The resultsindicate that openness is positively associated with development and human capital. Similarly, Romalis (2006) conducted a study where he argues that as the income goes up of the giant business partners such as US it becomes the cause ofextension in the trade of business partners. He also suggests that if the rich countries reduced tariff barriersto make imported goods cheaper will help the poor nations to grow their trade by one third to their GDP. Dava (2012) recommended in a study that the positive effect of free trade is larger and lead to efficiency in production and consumption. It can also help to improve annual growth rate by 0.6 to 1.6 percent.Another study suggests that countries with more potential to have trade are better off as openness and growth have a positive relation (Sarkar, 2006). His results are based on a time series date of 51 countries for a period of 1981-2002. But an interesting twist emerged when the countries were tested individually. In that case only the middle income countries showed to be better off.Chen and Gupta's (2006) study on the connection between openness and development in South African Development Community (SADC) suggests openness caused revolution in knowledge and technology which ultimately helped in their economic growth over the period of 1990-2003.

The study develop the following hypotheses, 
$\mathrm{H}_{0}$. There is a positive impact of trade liberalization on economic growth in the panel of Asian Economies

$\mathrm{H}_{1}$. The impact of trade liberalization in Asian economies is negative

\section{Methodological Framework Model Specification}

The elementary aim of the present study was to analyze the impact of the trade liberalization on the economic growth for the ASIAN economies, for this purpose it utilizes the following growth Equation.

GDP per capita could be the function of remittances, financial development, FDI, international trade or trade openness, gross fixed capital formation and human development ${ }^{1}$.

GDP per capita $=\mathrm{f}$ (remittances, financial development, FDI, international trade openness, gross fixed capital formation, human development).

$G D P c_{i t}=\beta_{\circ}+\beta_{1} \operatorname{Rem}_{i t}+\beta_{2} F_{i n D}+\beta_{3} \operatorname{Tr} d O_{i t}+\beta_{4} F D I_{i t}+\beta_{5} G F C F_{i t}+\beta_{6} H C_{i t}+$ $U_{i t} \ldots \ldots . . . .(1)$

Where:

$$
\begin{aligned}
& \text { Rem }_{i t}=\text { Remittances } \\
& \text { FinD }_{i t}=\text { Financial development } \\
& \operatorname{Trd} O_{i t}=\text { Trade openness } \\
& F D I_{i t}=\text { Foreign direct investemnt } \\
& G F C F_{i t}=\text { Gross fixed capital formation } \\
& H C_{i t}=\text { Human capital }
\end{aligned}
$$

\section{Sample Selection}

$$
U_{i t}=\text { error term or unobserved factors }
$$

This study selected ASIAN economies and the selection was made on the basis of data availability and the time period 1985-2014 has been taken as sample period. Panel data selection over time series and cross sectional data was due to its large number of data points which helps in reducing the probability of multicollinearity and higher degree of freedom which make it offer efficient parameter estimates (Hsiao, 2014). Further, the impact of unobservable and immeasurable aspectscan be controlled, each individual heterogeneity could be taken care of and the issue of absent variables could be undertaken.

\footnotetext{
${ }^{1}$ The selection of variables in growth equations is based on the literature.
} 


\section{Data source}

Data on the variables remittances, financial development foreign direct investment, trade openness, gross fixed capital formation have been taken from world development indicator (WDI). While human capital data has been obtained from data pen world table 8 (PWT)2.

\section{Estimation Technique}

Fixed Effect Model (FEM) and Random Effect Model (REM) are the two commonly used models in panel data examination (Manwa, et al., 2019). The Hausman test is used to select a model between FEM and REM. In FEM the unnoticed heterogeneity is preserved in intercept and in REM it is allowed to the error term. To do so in FEM we put a dummy variable for each cross sectional unit, the intercept of each unit is time variant and unique. We can use these models but since we have long time series panel data so these models could not take care of time series properties of the panel data thus it will be worthwhile to use the GMMto handle the issue of unit root. Beside these, GMM approach has several other advantages as well, like it avoid the problems of potential endogeneity and reverse causality ${ }^{3}$, mostly the estimated model not homoscedastic and serially independent, therefore, in the presence of heteroscedasticity only the GMM can produce efficient and consistent estimates. System GMM has two equations; one equation is about level form and uses suitable lag level as tool and the second equation is in difference form and as a tool uses the lag first difference. System GMM combines these two moments' conditions, cover level, and difference equation.

\section{Analytical Framework}

To analyze the impact of openness and other factors on GDP per capita, we first calculated, Arellano-Bond AR test and Hausman test of over-identifying restrictions ${ }^{4}$. The null hypothesis of Arellano-Bond AR tests the validity of instruments or no correlation to error term, while the Hausman test is used to test the null hypothesis that all instruments are exogenous indicated by high probability value (P-Value) of 0.971 , at this value we cannot reject the null hypothesis that instruments as a group are exogenous. The P-Value of AR (2) test is high as well with 0.925 , hence the null hypothesis regarding instruments validity could not be rejected. The associated coefficient with remittances $\left(R e m_{i t}\right)$ appear with positive and significant sign in all 5 models. Which implies remittances positively affect economic growth in ASIAN economies.

This finding is supported by the economic theory that a rise in the inflow of remittances boost up domestic saving level, create more investment opportunities and thus leads to higher economic growth.

\footnotetext{
${ }^{2}$ Definitions of the variables could be found in appendix A.

${ }^{3}$ As the literature suggest that trade openness is endogenous Variable, so using FE or RE will produce inefficient estimators.

${ }^{4}$ When we use robust standard error (which auto correct panel specific Heteroskedasticity and Autocorrelation) then the $\mathrm{p}$-value of Hansen test is considered instead of Sargent test.
} 
Table 4.1: Effect of Remittances and Other Factors on Output Volatility $\left(\sigma_{i t}\right)$

\begin{tabular}{|c|c|c|c|c|c|}
\hline VARIABLES & $\begin{array}{l}(1) \\
O L S\end{array}$ & $\begin{array}{l}(2) \\
F E \\
\end{array}$ & $\begin{array}{l}(3) \\
R E \\
\end{array}$ & $\begin{array}{c}(4) \\
I V F E \\
\end{array}$ & $\begin{array}{c}(5) \\
G M M \\
\end{array}$ \\
\hline$\sigma_{i t-1}$ & & & & & $\begin{array}{l}0.944 * * * \\
(0.0261)\end{array}$ \\
\hline $\operatorname{Rem}_{i t}$ & $\begin{array}{c}0.00553 * * * \\
(0.00177)\end{array}$ & $\begin{array}{l}0.164 * * * \\
(0.0498)\end{array}$ & $\begin{array}{c}0.0694 * * * \\
(0.0235)\end{array}$ & $\begin{array}{l}0.197 * * * \\
(0.0177)\end{array}$ & $\begin{array}{l}0.000635^{*} \\
(0.000366)\end{array}$ \\
\hline$F_{i n} D_{i t}$ & $\begin{array}{c}0.183 * * * \\
(0.0507)\end{array}$ & $\begin{array}{c}0.869 * * * \\
(0.299)\end{array}$ & $\begin{array}{c}0.739 * * * \\
(0.214)\end{array}$ & $\begin{array}{l}0.845^{* * * *} \\
(0.0978)\end{array}$ & $\begin{array}{l}0.0442 * * \\
(0.0187)\end{array}$ \\
\hline $\operatorname{Trd} O_{i t}$ & $\begin{array}{l}0.832 * * * \\
(0.00599)\end{array}$ & $\begin{array}{l}0.600 * * * \\
(0.0780)\end{array}$ & $\begin{array}{l}0.664 * * * \\
(0.0590)\end{array}$ & $\begin{array}{l}0.617 * * * \\
(0.0196)\end{array}$ & $\begin{array}{r}0.0407 * \\
(0.0228)\end{array}$ \\
\hline$F D I_{i t}$ & $\begin{array}{l}0.00983^{*} \\
(0.00555)\end{array}$ & $\begin{array}{c}0.00361 \\
(0.00394)\end{array}$ & $\begin{array}{c}0.00386 \\
(0.00405)\end{array}$ & $\begin{array}{c}0.00166 \\
(0.00293)\end{array}$ & $\begin{array}{c}0.00627 * * \\
(0.00302)\end{array}$ \\
\hline$G F C F_{i t}$ & $\begin{array}{l}0.825 * * * \\
(0.00692)\end{array}$ & $\begin{array}{c}0.645^{* * *} * \\
(0.188)\end{array}$ & $\begin{array}{l}0.666 * * * \\
(0.0677)\end{array}$ & $\begin{array}{r}0.613 * * * \\
(0.0482)\end{array}$ & $\begin{array}{c}0.0335 \\
(0.0218)\end{array}$ \\
\hline$H C_{i t}$ & $\begin{array}{l}0.0348 * \\
(0.0203)\end{array}$ & $\begin{array}{l}0.148 * * * \\
(0.0445)\end{array}$ & $\begin{array}{l}0.140 * * * \\
(0.0420)\end{array}$ & $\begin{array}{c}0.0942 * * * \\
(0.0186)\end{array}$ & $\begin{array}{l}0.0221 * * * \\
(0.00836)\end{array}$ \\
\hline Constant & $\begin{array}{c}2.587 * * * \\
(0.151)\end{array}$ & $\begin{array}{c}3.459 \\
(2.662)\end{array}$ & $\begin{array}{c}2.751 * * * \\
(0.972)\end{array}$ & $\begin{array}{c}2.603 * * * \\
(0.735)\end{array}$ & $\begin{array}{l}-0.0714 \\
(0.0735)\end{array}$ \\
\hline Observations & 952 & 952 & 952 & 952 & 952 \\
\hline R-squared & 0.972 & 0.804 & & & \\
\hline $\begin{array}{l}\text { Number of cross- } \\
\text { sections }\end{array}$ & & 34 & 34 & 34 & 34 \\
\hline $\begin{array}{l}\text { Arellano-Bond test for } \\
\text { AR(2) P-Value }\end{array}$ & & & & & 0.925 \\
\hline $\begin{array}{l}\text { Hansen test of overid: } \\
\text { restrictions }\end{array}$ & & & & & 0.971 \\
\hline
\end{tabular}

Robust standard errors in parentheses, $* * *, * *$ and $*$ represent $1 \%, 5 \%$ and $10 \%$ significance level 
Similarly the associated coefficient of financial development $\left(F i n D_{i t}\right)$ has also positive and significant effect on growth and is supported by the study of Goldsmith's (1969). In fact financial development is an important factor in reducing macro-economic instability and promoting growth. When financial development happens, it becomes easier for economic agents to react optimally to any economic shocks. As a result the economic interaction in the economy verves smoothly. Trade openness $\left(\operatorname{Tr} d O_{i t}\right)$ which is the variable of our interest is also appeared positive and significant, which suggest that as the economy become more opened to foreign trade, there is more chances that economy will have more a higher economic growth. Trade openness allows the utilization of comparative advantage, diffusion of knowledge, increasing scale economies, transfer of technology and exposure to competition. The same conclusion was also drawn by Romalis (2006) and Levine and Renelt (1992). Foreign direct investment $\left(F D I_{i t}\right)$ has positive and significant sign which is supported by the study of Borenzstein., et al (1988), which argued that foreign direct investment helps in economic growth through technology diffusion and human capital promotion. Similarly, the coefficient associated with gross fixed capital formation $\left(G F C F_{i t}\right)$ has also positive and significant association with GDP growth. This finding is consistent with the study of (Ndambiri et al, 2012) who also found positive and statistically significant effect of physical capital on economic growth. This result is also supported by the theory which suggest that as the volume of gross fixed capital increases, the availability of capital per worker increases which in turn enhances the growth pace. The coefficient associated with human capital (HCit) shows positive and significant effect on growth as well, which suggest that as the workers get more skill and education, their average productivity increases which is in lines with the study of (Levine and Renelt, 1992).

\section{Conclusion and Policy Recommendations}

The core objective of the present study was to investigate the effect of the openness on economic growth in a panel of ASIAN economies. We have employed Generalized Method of Moment (GMM).In our analysis we observed that there is positive and significant relationship between openness (trade liberalization) and economic growth. Trade openness also increases exposure to competition, technology transfer and knowledge diffusion. On the basis of the findings of this study suggest that trade liberalization policy should be adopted and promoted by the ASIAN economies, as it has favorable effect on their economic growth.

\section{References}

Alcala, F. \& Ciccone, A. (2003). "Trade and Productivity" CERR Discussion Paper No. 3095 (London: Centre for Economic Policy Research).

Barro, R.J. \& Lee, J.W. (1994). Sources of economic growth, Carnegie-Rochester Conference 
Barro, R.J. \& Sala-i-Martin, X. (1995). Economic Growth, McGraw-Hill, Cambridge, MA.

Bouoiyour, J. (2003). Trade and GDP Growth in Morocco: Short-run or Long-run Causality?, Brazilian Journal of Business and Economics, Vol 3. No. 2, pp. 14- 21. Behrman, J. \& Srinivasan T. N. (1995). "HandBook of Development Economics"; Elsevier Science: The Netherlands.

Borensztein, E., J. De Gregorio \& Lee, J. W. (1998). How does foreign direct investment affect economic growth?. Journal of International Economics, 45(1): 115-135.

Chen, P. P. \& Gupta, R. (2006). An investigation of Openness and Economic Growth Using panel Estimation, University of Pretoria, Working Paper: 2006-22. Dava, E. (2012, September). Trade liberalization and economic growth in the SADC: A difference in difference analysis. In IESE conference paper (No. 8).

David \& Schott (2005). Macroeconomics: Understanding the Wealth of Nations, A Handbook Published by John Welly \& Sons: Ed. New York.

Dollar, D. (1992). Outward-oriented Developing Economies Really Do Grow More Rapidly: Evidence from 95 LDCs, 1976-85, Economic Development and Cultural Change, Vol. 40, No. 3,pp. 523-44.

Dollar, D. \& Kraay, A. (2002). Growth is good for the poor. Journal of Economic Growth, Vol. 7.

Easterly, W. \& Levine, R. (2001). What have we learned from a decade of empirical research on growth? It's Not Factor Accumulation: Stylized Facts and Growth Models, World Bank, Economic Review, Vol. 15, No. 2, pp 177-219.

Edwards, S. (1998). Openness, Productivity, and Growth: What Do We Really Know?, Economic Journal, Vol.108 (447), pp. 383-98.

Fukuda, K. (2019). Effects of trade liberalization on growth and welfare through basic and applied researches. Journal of Macroeconomics, 62.

Goldsmith R.W. (1969). Financial Structure and Development”, New Haven, CT, Yale University Press.

Greenway, D., M., Wyn. \& Wright, P. (2002). Trade Liberalisation and Economic Growth in Developing Countries, Journal of Development Economics, 67:1. 229244.

Grossman, G.M. \& Helpman, E. (1991). Innovation and Growth in the Global Economy, Cambridge, MA: MIT Press.

Harrison, A. (1996) Openness and Growth: A Time-Series, Cross-Country Analysis for Developing Countries, Journal of Development Economics, Vol 48, No. 2, pp. 419-47.

Zafar, I. \& Zahid, G.M. (1998). Macro economic determinants of Economic growth in Pakistan, Pakistan Development Review 37(2): 125-48.

Irwin, D.A. \&Tervio, M. (2000). Does trade raise income? Evidence from the twentieth century, Journal of International Economics, Vol. 58, No. 1, pp.1-18. 
Islam M.N. (1998). Export expansion and economic growth: testing for cointegration and causality, Applied Economics, Vol. 30, No. 3, pp. 415-425.

Kemal, A.R. et al. (2003). An assessment of the impact of Trade Liberalization in Welfare in Pakistan (Islamabad: MIMAP, Technical Paper Series 16, PIDE).

Kemal, A.R., Din, Musleh-ud., \& Qadir, U. (2002). Global research Project: Pakistan Country Report on Sources of Economic Growth, Pakistan Institute of Development Economics: Islamabad.

Khan, M.A \& Qayyum, A. (2007). Trade Liberalization, Financial Development and Economic Growth, Pakistan Institute of Development Economics Working Paper Islamabad.

Krugman, P. (1994). The Myth of Asia's Miracle, Foreign Affairs, Vol. 73, No. 6, pp. 6278.

Krugman, P.R. (1979). Increasing returns, monopolistic competition and international trade. Journal of International Economics 9 (4): 469-479.

Krugman, P.R. (1980). Scale economies, product differentiation, and the pattern of trade. American Economic Review 70 (5): 950-959.

Levine, R., \& Renelt, D. (1992). A sensitivity analysis of cross-country growth regressions. The American Economic Review, 942-963.

Adebiyi, M. A. (2006). Trade Liberalization Policy and Industrial Growth Performance in Nigeria: An Error Correction Mechanism Technique.

Manwa, F., Wijeweera, A., \& Kortt, M. A. (2019). Trade and growth in SACU countries: A panel data analysis. Economic Analysis and Policy, 63, 107-118.

Mohsin, M.H. et al. (2001). Impact of Trade Reforms on Poverty, PIDE 16th

AnnualGeneral Meeting: Islamabad. No. 3, pp. 195-- 225.

Nourzad, F. \& Powell, J. J. (2003). Openness, Growth and Development: Evidence from a panel of developing countries, Scientific Journal of Administrative Development, Vol.

1. No.1.

Obstefled \& Rogoff, (1996). Foundations of International Macroeconomics. Cambridge MIT Press.

Pradhan, R. P., Arvin, M. B., Hall, J. H., \& Norman, N. R. (2017). ASEAN economic growth, trade openness and banking-sector depth: The nexus. EconomiA, 18(3), 359-379. proceedings of the World Bank annual conference on development economics, 1992, ed.

Rodrik, D. \&Rodríguez, F. (2001), Trade Policy and Economic Growth: A Skeptic Guide to the Cross-National Evidence, in B. Bernanke and K. Rogoff (editors), NBER Macroeconomics Annual 2000, Vol. 15, MIT Press, pp. 261-325.

Romalis, J. (2006). Market Access, Openness and Growth, National bureau of economic research (NBER), Working paper No. 13048.

Romer, (1993). Two strategies for economic development: Using ideas and producing ideas.

Romer, D. \& Frankel, J. A. (1999). Does Trade Cause Growth?”, The American Economic Review, Vol. 89, No. 3, pp. 379-399. 
Sarker, P. (2006). Trade Openness and growth: Is there any link?, Social Science Research Network, Political Economy Seminar (10 OCTOBER 2006), University of London. Series on Public Policy, Vol. 40, pp.1-46.

Sharer, Robert, and others, 1998, "Trade Liberalization In IMF-Supported Programs, World Economic and Financial Survey (Washington: International Monetary Fund).

Sinha, D., \& Sinha, T.,(1999), “Openness, Investment and economic growth in Latin American countries", paper presented at the sixty third annual meeting of the Midwest Economic Association, Nashvile, Tennnessee.

Stern, N., (2001). Globalization, Investment Climate and Poverty Reduction, Mimeographed. Summers, L.H; Shah, S., pp. 63--91. Washington, D.C.: World Bank.

Sun, P., Tan, Y., \& Yang, G. (2020). Export, FDI and the welfare gains from trade liberalization. Economic Modelling.

Waczairg, R. (1998). Measuring the dynamic gains from trade, World Bank Policy Research Working Papers 2001.

Winters \& Mackay, (2004). Trade liberalization and Poverty: The Evidence So Far, Journal of Economic Literature, 42(1), pp:72-115.

Winters, L.A. (2000b). Trade Liberalization and Poverty", Discussion Paper No7, Poverty Research Unit, University of Sussex.

Yang, Y. \& Haung Y., (1997). Impact of Trade Liberalisation on Income Distribution in China. Economic Division Working Papers No. 1. 


\section{Appendix A}

\section{Definitions of Variables}

\begin{tabular}{|c|c|}
\hline Variables Variable & Definition \\
\hline GDP per capita & $\begin{array}{l}\text { GDP per capita is gross domestic product divided by midyear } \\
\text { population. GDP is the sum of gross value added by all } \\
\text { resident producers in the economy plus any product taxes and } \\
\text { minus any subsidies not included in the value of the products. } \\
\text { It is calculated without making deductions for depreciation of } \\
\text { fabricated assets or for depletion and degradation of natural } \\
\text { resources. Data are in constant } 2005 \text { U.S. dollars. }\end{array}$ \\
\hline Trade openness & $\begin{array}{l}\text { Trade is the sum of exports and imports of goods and } \\
\text { services measured as a share of gross domestic product. }\end{array}$ \\
\hline Gross fixed capital & $\begin{array}{l}\text { Gross fixed capital formation (formerly gross domestic fixed } \\
\text { investment) includes land improvements (fences, ditches, } \\
\text { drains, and so on); plant, machinery, and equipment } \\
\text { purchases; and the construction of roads, railways, and the } \\
\text { like, including schools, offices, hospitals, private residential } \\
\text { dwellings, and commercial and industrial buildings. Net } \\
\text { acquisitions of valuables are also considered capital } \\
\text { formation. Data are in constant } 2005 \text { U.S. dollars. }\end{array}$ \\
\hline Human capital $/ 7 \mathrm{a} /$ & $\begin{array}{l}\text { Index of human capital per person, based on years of } \\
\text { schooling and returns to education }\end{array}$ \\
\hline Financial Development & $\begin{array}{l}\text { It is the amount of credit given to private sector. Data are in } \\
\text { constant } 2005 \text { U.S. dollars. }\end{array}$ \\
\hline Foreign direct investment & $\begin{array}{l}\text { Foreign direct investment are the net inflows of investment to } \\
\text { acquire a lasting management interest ( } 10 \text { percent or more of } \\
\text { voting stock) in an enterprise operating in an economy other } \\
\text { than that of the investor. It is the sum of equity capital, } \\
\text { reinvestment of earnings, other long-term capital, and short- } \\
\text { term capital as shown in the balance of payments. This series } \\
\text { shows net inflows (new investment inflows less } \\
\text { disinvestment) in the reporting economy from foreign } \\
\text { investors, and is divided by GDP }\end{array}$ \\
\hline
\end{tabular}

